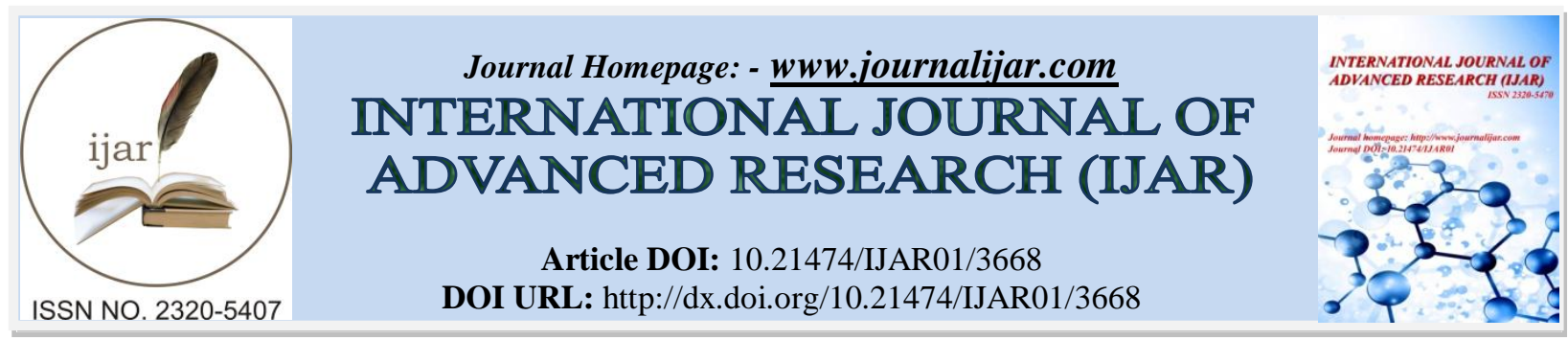

RESEARCH ARTICLE

\title{
EFFECT OF FROZEN STORAGE AND CRYOPROTECTANTS ON FUNCTIONAL PROPERTIES OF TILAPIA (Oreochromis mossambicus) FISH
}

\section{"Lakshmi Narasimha Murthy ${ }^{1}$, Girija Gajanan Phadke1, Vijaya Kumar Siddaiah', Rajanna Karani Boraiah ${ }^{3}$ and Chandra Madhamuthanalli Venkataramappa ${ }^{4}$.}

1. ICAR-Mumbai Research Centre of Central Institute of Fisheries Technology, CIDCO, Admin Bldg, Sector-1, Vashi, Navi Mumbai - 400703, Maharashtra, India.

2. Fisheries Research and Information Centre, Bhutanal, Vijayapura - 586103, Karnataka, India.

3. Fisheries Research and Information Centre (Inland), $10^{\text {th }}$ cross, Mayura Street, Papanna Layout, Hebbal Outer Ring Road, Bangalore - 560 094, Karnataka, India.

4. Department of Fish Processing Technology, Karnataka Veterinary, Animal and Fisheries Sciences University, College of Fisheries, Mangalore - 575 002, India.

\section{Manuscript Info}

Manuscript History

Received: 11 January 2017

Final Accepted: 05 February 2017

Published: March 2017

Key words:-

Tilapia, frozen storage, cryoprotectants, apparent reduced viscosity, calcium ATPase Activity, gel filtration profile

\section{Abstract}

In the present investigation, changes in functional properties of proteins from tilapia (Oreochromis mossambicus) in the form of whole tilapia (WHT), water washed minced meat of tilapia without addition of cryoprotectants (WMT) and with cryoprotectants (WMCT) during frozen storage have been evaluated. Gradual reduction in moisture content and marginal increase in protein content was observed in all the samples with progressive frozen storage. The reduction in non protein nitrogen (NPN) content was lower in WMCT as compared to WHT and WMT. All the samples exhibited decreased calcium-ATPase activity as a function of frozen storage. WMCT had a higher activity index during frozen storage as compared to WHT and WMT. The enzymatic activities decreased with progressive frozen storage period with relatively higher activity in WHT. Proteins from washed meat with cryoprotectants had minimum change in reduced viscosity profile at single protein concentration during different periods of frozen storage. Changes in structure of proteins were evident from apparent reduced viscosity and gel filtration profile as a function of frozen storage.

Copy Right, IJAR, 2017,. All rights reserved.

\section{Introduction:-}

Being a rich source of proteinaceous material, fish is consumed worldwide as a source of nutrition. Tilapia is becoming an increasing substitute for traditional white fish species. The consumption of tilapia in the year 2014 was around 5.4 MMT worldwide (Fernandes et al., 2015). Around 4\% of the catch spoils as a result of lacuna in transportation and storage conditions (Jackson et al., 1997). In order to increase the consumer preference for tilapia, value addition is one of the options. Due to the presence of bones, preparation of value added products is problematic. To overcome the problem, production of mince from fish by mechanical means is a good alternative. Fish mince needs freezing and frozen storage and can be a good source of raw material for production of various value added products (Venugopal and Shahidi, 1998).

Corresponding Author:- *Lakshmi Narasimha Murthy.

Address:- ICAR-Mumbai Research Centre of Central Institute of Fisheries Technology, CIDCO, Admin

Bldg, Sector-1, Vashi, Navi Mumbai - 400703, Maharashtra, India. 
Water washed mince meat blended with additives, frozen and stored under frozen storage is termed as surimi (Park and Lin, 2005). Few white flesh varieties are commercially used for production of large quantities of surimi. In India, surimi production accounted for 58000 million metric tonnes in the year 2011 (Park and Lin, 2013). Gelation behavior of fish on heat processing is an important characteristic in surimi production. Use of tilapia for production of surimi has been attempted (Pan et al., 2010). However, the information on changes in properties of tilapia proteins added with cryoprotectants during frozen storage is limited.

Due to the perishable nature of tilapia, frozen storage is required in order to maintain its quality. However, after prolonged storage even at temperatures below $-20^{\circ} \mathrm{C}$, marked undesirable sensory changes in the product take place. There are many reports on frozen storage of tilapia in relation to its biochemical, sensory and microbiological quality (Ng and Bahurmiz, 2009). Protein denaturation and/or aggregation may take place during frozen storage of tilapia meat (Shenouda, 1980). Protein denaturation leads to alteration of functional and gelation properties (Badii and Howell, 2001). Cryoprotectants are generally used to prevent these undesirable changes in the myofibrillar protein and to preserve maximum functionality of surimi (Yoon and Lee, 1990). It is well documented that these sugars work by stabilizing actomyosin, increasing surface tension (Arakawa and Timasheff, 1982) and the amount of bound water, preventing protein water loss (Buttkus, 1970) and maintaining protein solubility (Herrera and Sampedro, 2002). A mixture of sucrose and sorbitol is the preferred as cryoprotectant for fish surimi as both have excellent cryoprotective effects on fish myofibrillar protein (Yoon and Lee, 1980).

Utilization of tilapia has been attempted to produce surimi and have been found to be suitable for surimi production (Park et al., 1990). Properties of the protein of fish intended for surimi production play a pivotal role in the end product quality (Murthy and Rajanna, 2011). In order to produce mince based products from tilapia, it is essential to have understanding of properties of proteins during frozen storage so as to improve the textural properties. The aim of this study was to evaluate the effect of freezing and frozen storage on the quality of tilapia with and without cryoprotectants. We investigated freeze-induced denaturation of samples by evaluation of $\mathrm{Ca}^{++}$-ATPase activity, MIPase activity of tilapia fish mince with and without addition of cryoprotectants.

\section{Methodology:-}

\section{Raw material:-}

Fresh tilapia (Oreochromis mossambicus) caught from natural freshwater body near Mysore, Karnataka, India was used for the study. The length of fish used was 21 to $28.5 \mathrm{~cm}$, weighing 150 to $340 \mathrm{~g}$. The fish samples were washed and iced in the ratio of 1:1 (fish: ice) and transported to the laboratory immediately after harvest. Head and entrails were removed manually, washed with chilled water $\left(3^{\circ} \mathrm{C}\right)$ and subjected to further analysis.

\section{Chemicals and reagents:-}

Sodium chloride, sodium di-hydrogen phosphate, di-sodium hydrogen phosphate, tri-chloro acetic acid (TCA) were procured from E-Merck India Limited. Ellman reagent was procured from Sigma Chemical co., St. Louis, USA. The synthetic Krehalan casings (copolymer of vinylidene chloride and vinyl chloride) of size $50 \mathrm{~mm}$ x $280 \mathrm{~mm}$ (diameter $x$ length) were obtained from Kruhea Chemical industry Co. Ltd., Japan. All chemicals and reagents used in the present study were of AR or GR grade.

\section{Freezing and frozen storage:-}

From minced meat, surimi was prepared from minced meat (Nishiya et al., 1961) and mixed with cryoprotectants $(\mathrm{w} / \mathrm{w})$ such as sodium tri-poly phosphate $(0.2 \%)$, sorbitol $(4 \%)$ and sucrose $(4 \%)$. The fish meat packed in polyethylene bags was frozen in air blast freezer at $-35^{\circ} \mathrm{C}$. The total time for freezing was 4 to 6 hours. Whole fish were frozen in similar fashion. All three, washed meat (WMT), washed meat with cryoprotectants (WMCT) and whole fish (WHT) frozen samples were stored in deep freezer (Vest frost, Holland) at $-20 \pm 2{ }^{\circ} \mathrm{C}$ during the period of study. Samples were drawn at regular intervals up to 360 days frozen storage period.

Changes in properties of proteins from whole fish, washed meat and washed meat with cryoprotectants of tilapia fish meat during frozen storage:

Changes in moisture, total protein content and non-protein nitrogen (NPN) content:-

The samples were macerated well using a pestle and mortar and the macerated meat was used. Moisture and protein in the meat were determined as per AOAC, 2000. NPN content was determined by TCA method (Velankar and Govindan, 1958). About $5 \mathrm{~g}$ of meat was ground with $10 \mathrm{ml}$ of $15 \%$ TCA for $5 \mathrm{~min}$ using pestle and mortar. The 
slurry was filtered and made up to $50 \mathrm{ml}$ with distilled water and $5 \mathrm{ml}$ of aliquot was taken for nitrogen estimation by Kjeldahl method.

\section{Changes in apparent reduced viscosity:-}

Total proteins from tilapia meat were extracted using phosphate buffer $(50 \mathrm{mM}, \mathrm{pH} 7.5)$ containing $1 \mathrm{M} \mathrm{NaCl}$ referred to as extraction buffer (EB) and the solution was used for viscosity measurements. Ostwald viscometer with capillary diameter of less than $0.5 \mathrm{~mm}$ was used. The temperature of the viscosity measurements was done at $25 \pm 1^{\circ} \mathrm{C}$. The ratio of fish meat to buffer for extraction of proteins was 1:10. The clear supernatant obtained was taken for viscosity measurements after determining protein concentration by Lowry's method (Lowry et al., 1951). Appropriate dilutions of protein solution were made using EB as solvent so as to get different concentration of protein solution. A known quantity of protein solution $(10 \mathrm{ml})$ was taken into viscometer and equilibrated in a water bath at $25 \pm 1{ }^{\circ} \mathrm{C}$ for $15 \mathrm{~min}$. Time taken by the protein solution to pass through the two markings on the viscometer was monitored with the help of a stop watch (Rocar, Switzerland) with $0.2 \mathrm{sec}$ sensitivity. The solution was taken up to mark by suction and the flow time in seconds required to flow between the markings in viscometer was recorded. For each protein concentration 3 readings were taken and the average flow time was used for calculation.

Apparent reduced viscosity was calculated using the following formula (Yang, 1961) and expressed as $\mathrm{ml} / \mathrm{mg}$ of protein in the solution. Apparent reduced viscosity was plotted against different protein concentration $(\mathrm{mg} / \mathrm{ml})$.

$\eta_{\text {red }}=\frac{t_{1}-t_{0}}{t_{0} X C}$

Where;

$\eta_{\text {red }}=$ reduced viscosity $(\mathrm{ml} / \mathrm{mg})$

$\mathrm{t}_{1}=$ flow time for protein solution $(\mathrm{sec})$

$\mathrm{t}_{0}=$ flow time for solvent, $\mathrm{EB}(\mathrm{sec})$

$\mathrm{C}=$ concentration of protein in the solution $(\mathrm{mg} / \mathrm{ml})$

\section{Changes in calcium ATPase activity:-}

Calcium ATPase activity was measured by using spectro-photometric method (Noguchi and Matsumoto, 1970). About $1 \mathrm{~g}$ of meat was homogenized in $10 \mathrm{ml}$ of $0.05 \mathrm{M}$ Tris-HCL buffer, $\mathrm{pH} 8.0$. The homogenate was centrifuged at $8000 \mathrm{x}$ g using IEC B22 high speed refrigerated centrifuge for 15 minutes at $4^{\circ} \mathrm{C}$. The supernatant thus obtained was used as a source of enzyme. The reaction mixture consisting of $0.06 \mathrm{ml}$ of $0.05 \mathrm{M}$ adenosine tri-phosphate (ATP) solution, $0.4 \mathrm{ml}$ calcium chloride $(0.1 \mathrm{M}), 2 \mathrm{ml}(0.05 \mathrm{ml})$ Tris- $\mathrm{HCl}$ buffer $(\mathrm{pH} 8.0)$. About $0.4 \mathrm{ml}$ meat extract was added to reaction mixture and incubated for 5 minutes at $28 \pm 1{ }^{\circ} \mathrm{C}$. The reaction was stopped by adding $2 \mathrm{ml}$ of $15 \%$ TCA. All the assays were done with both samples blank as well as reagent blank in triplicate. The mixture was filtered, the inorganic phosphorous in the filtrate was determined (Taussky and Shorr, 1952). To the $2 \mathrm{ml}$ filtrate, 3 $\mathrm{ml}$ of ammonium molybdate ferrous sulphate solution (freshly prepared) was added. The intensity of the colour developed was read at $660 \mathrm{~nm}$. The concentration of liberated inorganic phosphate was measured using standard curve obtained by using potassium di-hydrogen phosphate as a standard. The activity was expressed as $\mu \mathrm{g} \mathrm{P}_{\mathrm{i}} / \mathrm{mg}$ protein/ minute. The initial calcium ATPase activity was taken as 100 and designated as activity index.

\section{Changes in modori inducing proteases (MIPase) activity:-}

Modori inducing protease in tilapia meat was determined spectrophotometrically (An et al., 1994). The crude enzyme extract was prepared by homogenizing $5 \mathrm{~g}$ of fresh tilapia meat with $15 \mathrm{ml}$ phosphate buffer $(50 \mathrm{mM}$; $\mathrm{pH}$ 7.5 ) at $3000 \mathrm{rpm}$ for 2 minutes in the homogenizer (Nihon Seiki Kogyo Co., Tokyo, Japan). The homogenate was centrifuged at $8000 \mathrm{x} \mathrm{g}$ for 15 minutes. The supernatant was diluted with phosphate buffer in the ratio of 1:1 and used as crude enzyme extract. The substrate solution was prepared by dissolving $4 \mathrm{mg}$ casein (according to Hammerstein) in $1.25 \mathrm{ml}$ phosphate buffer $(50 \mathrm{mM}, \mathrm{pH} 7.5)$ and making up to $2 \mathrm{ml}$ with distilled water. To determine the modori inducing protease activity, $2 \mathrm{ml}$ of the substrate solution was pre-incubated at $55 \pm 1^{\circ} \mathrm{C}$ for 5 minutes in water bath. To this $0.5 \mathrm{ml}$ of crude enzyme was added and again incubated at $55 \pm 1^{\circ} \mathrm{C}$ for 1 hour for the enzymatic reaction to occur. The reaction was terminated by adding $1 \mathrm{ml}$ cold $20 \%$ TCA. The slurry was centrifuged at $8000 \mathrm{x} \mathrm{g}$ for $15 \mathrm{~min}$ at $4^{\circ} \mathrm{C}$. The supernatant containing the hydrolyzed oligo peptide was collected without disturbing the pellet. The oligo peptide content in the supernatant was determined by measuring the absorbance at $280 \mathrm{~nm}$ in a UV- VIS Spectrophotometer (Spectronic 21 Bausch and Lomb, USA). The blank was prepared in the same manner except that the crude enzyme extract was added immediately after TCA precipitation. The enzyme 
activity was expressed as the difference of absorbance at $280 \mathrm{~nm}$ between the sample and the blank. The concentration of protein in the crude enzyme was estimated by measuring absorbance at $280 \mathrm{~nm}$.

\section{Changes in gel filtration profile:-}

Gel filtration profile of WHT, WMT and WMCT samples as a function of frozen storage was carried out on a sepharose 6B gel packed in a column of $1.5 \times 80 \mathrm{~cm}$ (dia x height) using EB as an eluent. Total bed volume of the column was $160 \mathrm{ml}$. The void volume (Vo) of column was determined using blue dextran and was found to be 50 ml. Two grams of meat sample was homogenized with $18 \mathrm{ml}$ EB using a homogenizer (Nihon Seiki Kogyo, Co., Japan) and the homogenate was centrifuged at $9000 \mathrm{X}$ g using IEC refrigerated centrifuge for 15 min at $4^{\circ} \mathrm{C}$. A clear supernatant $(1.5 \mathrm{ml})$ was loaded on to the top of gel column after determining the protein concentration. The protein concentration loaded to the column varied between $10-12 \mathrm{mg} / \mathrm{ml}$. Flow rate was adjusted to $30 \mathrm{ml} / \mathrm{hour}$ and fractions of $3 \mathrm{ml}$ were collected manually. The protein concentration was measured by taking absorbance at $280 \mathrm{~nm}$ using a UV/VIS spectrophotometer (Spectronic - 21, Bausch and Lomb, USA). A plot of absorbance at $280 \mathrm{~nm}$ against elution volume was obtained to get the gel filtration profile.

\section{Statistical Analysis:-}

In order to assess the effect of frozen storage period and cryoprotectants from different sources on various properties of tilapia meat, two-way analysis of variance (ANOVA) without replication was carried out using MS-Excel.

\section{Results and Discussion:-}

\section{Physical characteristics of fresh tilapia meat:-}

The fishes used in the present study were relatively big in both size and weight. The dressing yield (after removal of head, entrails) was $64.3 \%$ and the meat yield from the whole fish was $44 \%$. Normally bigger size fish will give higher yield compared to small size fish. The yield of separated meat of the fresh water fishes like common carp and silver carp varies from 40-47 \% (Arekere, 1993; Siddaiah et al., 2001).

\section{Changes in moisture, total protein and non-protein nitrogen (NPN) content as a function of frozen storage period:-}

The changes in moisture content of whole fish (WHT), washed meat (WMT) and washed meat with cryoprotectants (WMCT) during frozen storage are given in Fig. 1a. The initial moisture content of washed meat was higher than whole fish meat. The increased moisture content of washed meat may be attributed to hydration of myofibrillar proteins (Suvanich et al., 2000; Karthikeyan et al., 2004). A reduction in moisture content was recorded as a function of frozen storage period in all the samples. It is usual to find reduction in moisture content of fish and fishery products during frozen storage because of dehydration (Shenouda, 1980). The moisture content of WMCT sample registered minimum changes during frozen storage. The variation in the moisture content of WHT, WMT and WMCT as a function of frozen storage was significant $(\mathrm{p}<0.05)$. Significant difference was also observed between WHT, WMT and WMCT for similar storage days $(\mathrm{p}<0.05)$. Similar type of reduction in moisture content was observed in croaker fish washed meat samples (Basavanagouda, 2001) and in pink perch surimi (Nopianti et al., 2012). Cryoprotectants added in the surimi reduced the protein aggregation by increasing the hydration and prevented drastic fall of moisture content.

The total protein content of samples as a function of frozen storage period showed a marginal increase in all the samples and is given in Fig. 1b. The initial protein content of whole fish and washed meat was found to be 17.47 and $12.80 \%$ respectively. Reduced protein content on washing has also been reported (Fogaca et al., 2015). Addition of cryoprotectants to washed meat reduced the total protein content. There was a gradual increase in protein content in all the three samples during frozen storage. Protein content of WHT sample was significantly higher than WMT and WMCT throughout the storage period $(\mathrm{p}<0.05)$. WMCT sample registered a higher increase in protein content than WMT possibly due to higher reduction in moisture content.

The changes in non-protein nitrogen (NPN) content of tilapia meat samples during different periods of frozen storage are given in Fig. 1c. There was a significant decrease in NPN content in all the samples throughout the storage period $(\mathrm{p}<0.05)$. The reduction in NPN content was higher WHT than WMT followed by WMCT. The results of analysis of variance indicated that the changes in NPN values were altered both due to storage and sample condition. The loss of NPN constituents in frozen fish may be observed due to the leaching effect during thawing. The initial NPN content of whole fish meat was $365 \mathrm{mg} \%$, which was more than that of washed meat indicating that washing has reduced the NPN content. Similarly washed meat of pink perch showed reduction in NPN content 
(Karthikeyan et al., 2006). The loss of NPN constituents in frozen fish meat is mainly due to leaching effect during thawing.

\section{Changes in apparent reduced viscosity as a function of frozen storage period:-}

Measurement of viscosity of protein samples has been used to determine the protein denaturation. A plot of frozen storage period $v s$ apparent reduced viscosity at a single protein concentration $(3 \mathrm{mg} / \mathrm{ml})$ was obtained (Fig. $2 \mathrm{a})$. All the three frozen stored samples initially showed an increasing trend and later the value decreased. The decrease was more rapid in washed meat samples without cryoprotectants. Denaturation of myofibrillar proteins lead to changes in viscosity due to the change in particle axis ratio (Suzuki, 1981). It could be seen that proteins from washed meat with cryoprotectants had minimum change in reduced viscosity profile at single protein concentration during different periods of frozen storage. This is due to the preferential hydration of protein molecules induced by added cryoprotectants. Similar reduction in apparent reduced viscosity has been reported for horse mackerel, blue whiting and croaker (Colmenero and Borderias, 1983; Basavanagouda, 2001). The apparent reduced viscosity of protein from tilapia clearly indicated that washed meat with cryoprotectant has undergone lesser degree of conformational changes than that of proteins from whole fish and washed meat.

\section{Changes in calcium ATPase activity as a function of frozen storage period:-}

The calcium activated ATPase activity which arises from globular head of myosin, S1 fraction is generally taken as an index of denaturation of fish proteins during ice storage and frozen storage (Lehninger, 1993; Lin and Park, 1998). The calcium ATPase activity of WHT, WMT and WMCT as a function of frozen storage period is given in Fig 2b. The reduction in enzyme activity index was higher in whole fish meat than washed meat and washed meat with cryoprotectants. The decrease in ATPase activity of all the three frozen tilapia samples was evident during different periods of frozen storage. Washed tilapia meat with cryoprotectants had a higher activity index during different periods of frozen storage in comparison to whole and washed tilapia meat. The effect of cryoprotectants in minimizing the aggregation/ denaturation is the possible reason for the retention of higher ATPase activity. $\mathrm{Ca}^{++}$ ATPase activity of actomyosin from tilapia fillets stored over 2000 atm showed apparently falling trend and the protein denatured evidently (Ko and Hsu, 2002). The present investigation indicates sucrose and sorbitol could minimize the reduction in $\mathrm{Ca}^{++}$ATPase activity during frozen storage by retarding the deteriorative reaction. Similar observations have been recorded for frozen stored tilapia (Sarotherodon nilotica) meat added with cryoprotectants (Zhou et al., 2006).

\section{Changes in modori inducing protease (MIPase) activity as a function of frozen storage period:-}

The MIPase are group of cathepsins present in muscle cell, hydrolyzing myofibrillar proteins or any other suitable substrates. The modori inducing protease activity of tilapia samples during different periods of frozen storage is given in Fig. 2c. The activity of enzyme decreased with increase in frozen storage period and relatively higher activity was observed in whole fish meat. It is evident that the initial MIPase activity of WHT was significantly higher than that of WMT and WMCT. It clearly suggests that MIPase activity is associated with sarcoplasmic fraction of the muscle and hence reduction in activity was observed in washed meat because of washing. Degradation of protein network during gelation process by cathepsin has been studied extensively. Tilapia surimi is known to have high proteolytic activity at $60^{\circ} \mathrm{C}$ (Yongsawatdigul et al., 2000). Sarcoplasmic fraction and MIPase activity are associated hence, washing reduces the MIPase activity.

\section{Changes in gel filtration profile as a function of frozen storage period:-}

Changes in gel filtration profile of WHT, WMT and WMCT samples during different from storage periods are given in Fig. 3. The gel filtration profile of total proteins from WHT showed more of low molecular weight components at the initial stage with further marginal increase in the high molecular weight components with progressive storage up to 90 days after which a gradual decrease in concentration was observed. The elution volume of high molecular weight fraction was shifted from $67.89 \mathrm{ml}$ in the fresh sample to $90.65 \mathrm{ml}$ at the end of 240 days of storage. At the end of 360 days of storage the elution volume was shifted to $74.4 \mathrm{ml}$. This clearly demonstrates that there is initial dissociation after which the association phenomenon has taken place. Altered elution profile indicated associationdissociation phenomenon (Binsi et al., 2007). In WMT sample, decrease in high molecular weight components at the end of 240 days storage period was recorded whereas WMCT sample revealed increase in high molecular weight components up to 90 days followed by low molecular weight components during storage period. WMT sample showed the dissociation phenomenon immediately after freezing whereas, WMCT sample exhibited relatively higher concentration of high molecular weight components throughout the storage period. The indication of high molecular weight components at relatively higher concentration indicated lesser extent of degradation. The data 
obtained on apparent reduced viscosity and gel filtration profile supported that there is a minimum conformational change in proteins in WMCT than WHT and WMT. Structural change of proteins during frozen storage was evident from reduced viscosity and gel filtration profile. Changes in protein structure as a function of frozen storage of common carp meat, tilapia were also reported (Ganesh et al., 2006; Murthy et al., 2011). Peak reduction may be attributed to removal of free amino acids, peptides and other low molecular weight compounds (Suvanich et al., 2000).

With the increasing production of tilapia catch, it is necessary to think towards better utilization of tilapia in order to get higher economic returns. Better utilization relies on understanding of fish in relation to the protein properties. Properties of proteins exhibited changes in structure as evident from gel filtration profile and apparent reduced viscosity values in all the samples namely whole fish, meat without and with cryoprotectants as a function of frozen storage. In order to utilize the catch throughout the year, use of cryoprotectants and frozen storage play an important role. Water washed frozen stored tilapia meat with cryoprotectants could be used in product development.
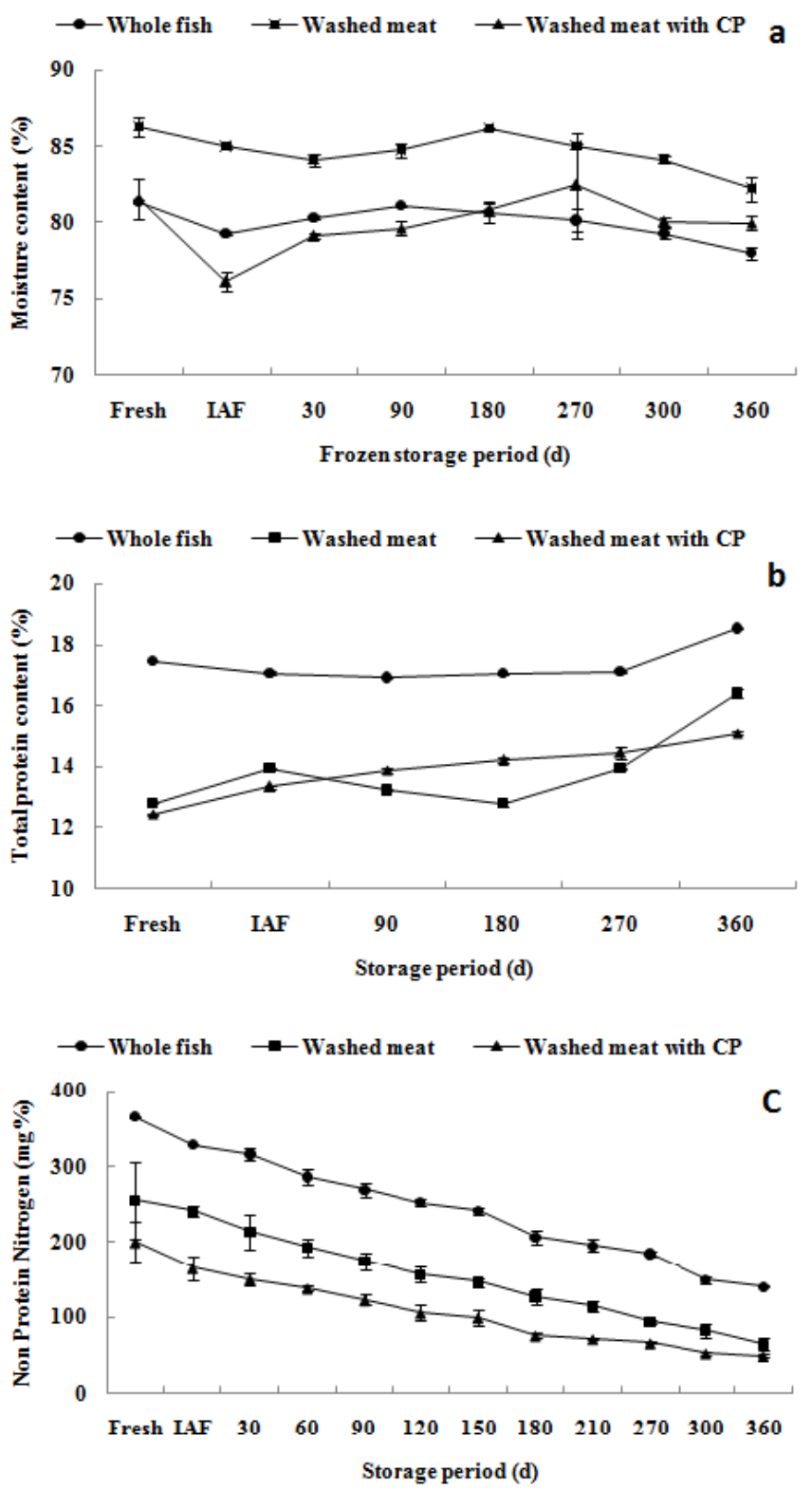

FIGURE 1:- Changes in composition of whole tilapia (WHT), washed tilapia meat without cryoprotectants (WMT) and washed tilapia meat with cryoprotectants (WMCT) as a function of frozen storage; a. Moisture content (\%); b.

Protein Content (\%); and c. Non-protein nitrogen (NPN) content (mg\%) 

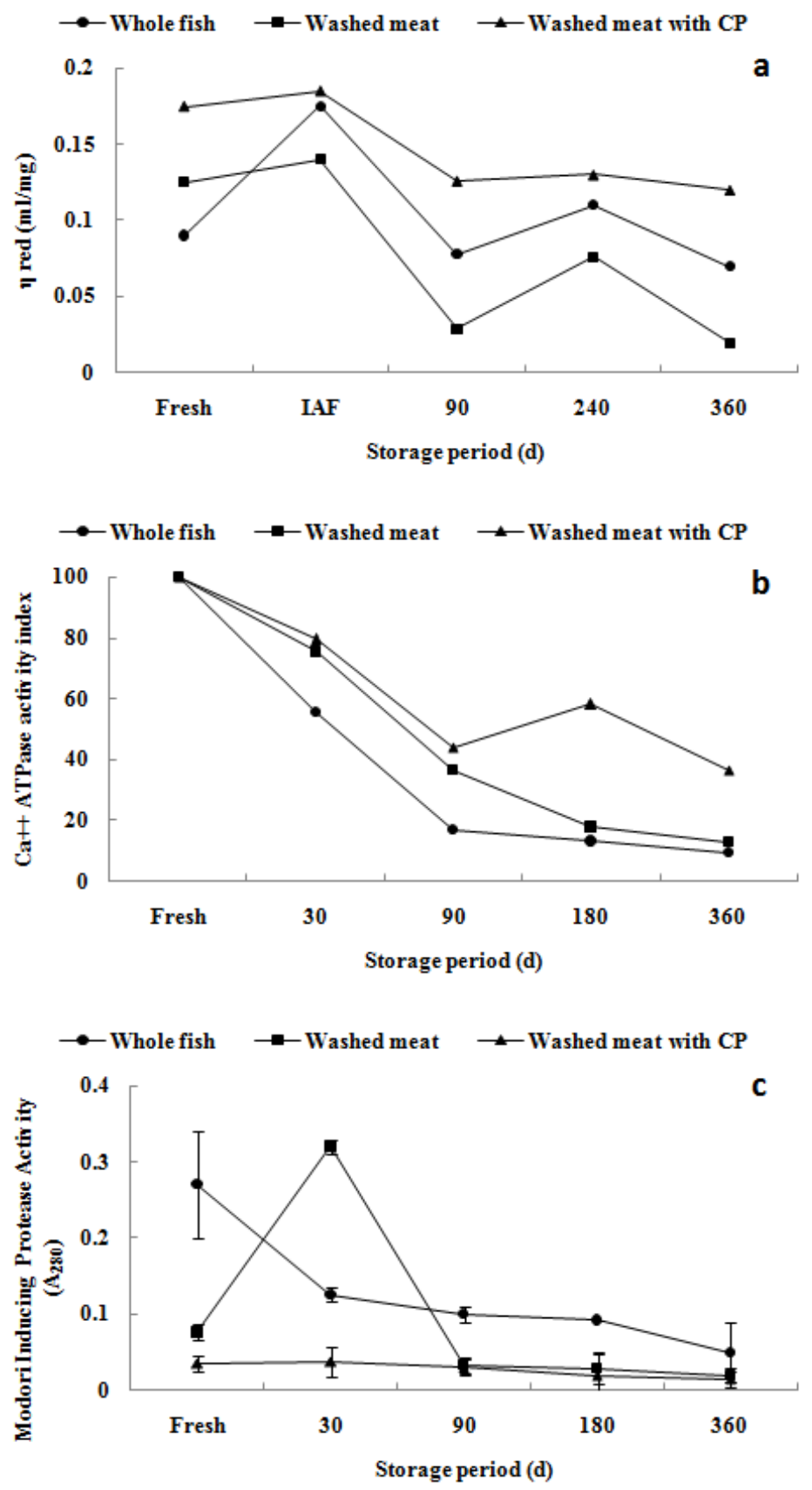

FIGURE 2:- Changes in properties of proteins of whole tilapia (WHT), washed tilapia meat without cryoprotectants (WMT) and washed tilapia meat with cryoprotectants (WMCT) as a function of frozen storage; a. apparent reduced viscosity (ml/mg); b. Calcium ATPase activity index; and c. Modori inducing proteases activity in terms of absorbance 

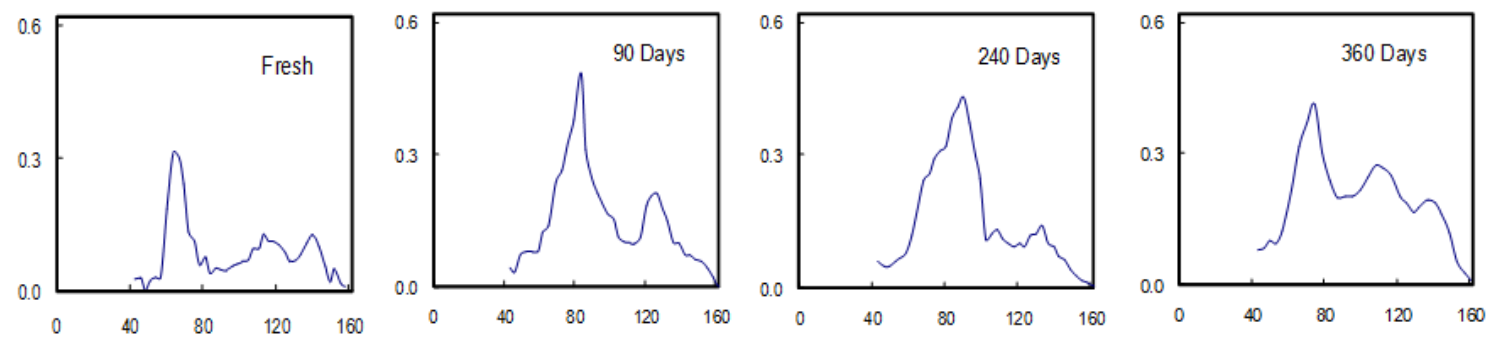

WHT
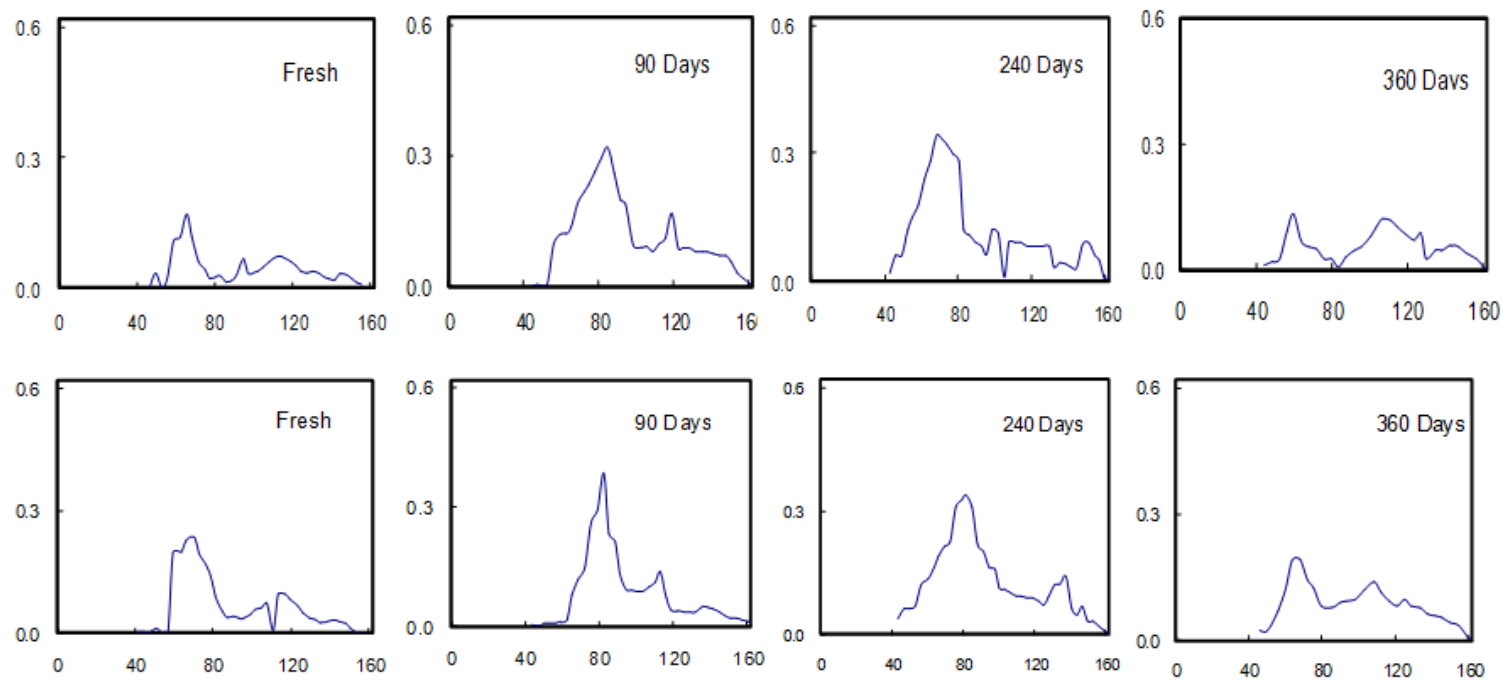

WMCT

FIGURE 3:- Changes in gel filtration profile of proteins of whole tilapia (WHT), washed tilapia meat without cryoprotectants (WMT) and washed tilapia meat with cryoprotectants (WMCT) as a function of frozen storage

\section{Acknowledgements:-}

The study was a part of doctoral research work and author would like to thank all the staff members of Fish Processing Technology department, College of Fisheries, Mangalore.

\section{References:-}

1. Tan, A., Voegtline, M., Bekele, S., Chen, C.S. and Aroian, R.V. (2008): Expression of Cry5B protein from Bacillus thuringiensis in plant roots confers resistance to root-knot nematode. Biol. Control., 47: 97-102.

2. Pandey, R. and Kalra, A. (2003): Root knot disease of ashwagandha Withania somnifera and its ecofriendly cost effective management. J. Mycol. Pl. Pathol., 33(2): 240-245.

3. Charnley, A.K. (1992): Mechanisms of fungal pathogenesis in insects with particular reference to locusts. In: Lomer CJ, Prior C (eds) Biological Controls of Locusts and Grasshoppers: Proceedings of an international workshop held at Cotonou, Benin. Oxford: CAB International, pp. 181-190.

4. An, H., Weerasinghe, V., Semour, T.A. and Morrissey, M.T. (1994): Cathepsin degradation of pacific whiting surimi proteins. J. Food Sci. 59(5): 1013-1033.

5. AOAC. 2000. Official methods of analysis of AOAC International, Horwitz, W. (eds.) AOAC International, Gaithersburg, Maryland, USA.

6. Arakawa, T. and Timasheff, S.N. (1982): Preferential interactions of proteins with salts in concentrated solutions. Biochem. 21(25): 6545-6552.

7. Arekere, G. (1993): Effect of freezing and frozen storage on the properties of proteins from common carp (Cyprinus Carpio). Post graduation dissertation, Univ. Agric. Sci., Bangalore, India.

8. Badii, F. and Howell, N.K. (2001): A comparison of biochemical changes in cod (Gadus morhua) and haddock (Melanogrammus aeglefinus) fillets during frozen storage. J. Sci. Food Agric. 82: 87-97.

9. Basavanagouda, N. (2001): Setting ability of surimi from croaker (Johnius spp.) fish meat: Effect of frozen storage and added cryoprotectants. Post graduation dissertation, University of Agricultural Sciences, Bangalore, India. 
10. Binsi, P.K., Shamasundar, B.A. and Dileep, A.O. (2007): Physico-chemical and functional properties of proteins from green mussel (Perna viridis) during ice storage. J. Sci. Food Agric. 87: 245-254.

11. Buttkus, H. (1970): Accelerated denaturation of myosin in frozen solution. J. Food Sci. 35: 558-562.

12. Colmenero, J.F. and Borderias, A.J. (1983): A study of the effects of frozen storage on certain functional properties of meat and fish proteins. J. Food Technol. 18: 731-737.

13. Fernandes, A.F.A., Silva, M.D., De-Alvarenga, E.R., Teixeira, E.D., Da-Silva, A.F. and Alves, G.F.D. (2015): Morphometric traits as selection criteria for carcass yield and body weight in Nile tilapia (Oreochromis niloticus L.) at five ages. Aquacult. 446: 303-309.

14. Fogaca, F.H., SantAnac, L.S., Larab, J.A.F., Maia, A.C.G. and Carneiroc, D.J. (2015): Restructured products from tilapia industry byproducts: The effects of tapioca starch and washing cycles. Food Bioprod. Proc. 94: 482-488.

15. Ganesh, A., Dileep, A.O., Shamasundar, B.A. and Singh, U. (2006): Gel forming ability of common carp fish (Cyprio carpio): effect of freezing and frozen storage. J. Food Biochem. 30: 342-361.

16. Herrera, J. and Sampedro, L. (2002): Effects of various cryostabilisers on protein functionality in frozen-stored minced blue whiting muscle: The importance of inhibiting formaldehyde production. Eur. J. Food Res. Technol. 214: 382-387.

17. Jackson, C.T., Acuff, R.G. and Dickson, J.S. (1997): Meat, poultry and seafood. In: Food Microbiology, fundamentals and frontiers. Doyle, M.P., Beuchat, L.R., and Montville, T.J. (Ed.) American Society for Microbiology, Washington. pp. 263-300

18. Karthikeyan, M., Dileep A.O. and Shamasundar B.A. (2006): Effect of water washing on the functional and rheological properties of proteins from threadfin bream (Nemipterus japonicus) meat. Int. J. Food Sci. Technol. 41: 1002-1010.

19. Karthikeyan, M., Shamasundar, B.A., Mathew, S., Ramesh Kumar, P. and Prakash, V. (2004): Physicochemical and functional properties of proteins from pelagic fatty fish (Sardinella longiceps) as a function of water washing. Int. J. Food Prop. 7(3): 353-365.

20. Ko, W.C. and Hsu, K.C. (2002): Effect of high-pressure storage on the processing quality of tilapia meat. Biotechnol. Prog. 19: 411-416.

21. Lehninger, A.L. (1993): The Molecular Basis of Cell Structure and Function. $2^{\text {nd }}$ Ed. Worth Publ. Inc., New York. pp. 1104.

22. Lin, T.M. and Park, J.W. (1998): Solubility of salmon myosin as affected by conformational changes at various ionic strengths and pH. J. Food Sci. 63: 215-218.

23. Lowry, O.H., Rosebrough, N.J., Farr, A.L. and Randall, R.J. (1951): Protein measurement with the Folin phenol reagent. J. Biol. Chem. 193: 265-275.

24. Murthy, L.N. and Rajanna, K.B. (2011): Effect of washing on composition and properties of proteins from Tilapia (Oreochromis mossambicus) meat. Fish. Technol. 48(2): 125-132.

25. Murthy, L.N., Panda, S.K. and Shamasundar, B.A. (2011): Physico-chemical and functional properties of proteins of tilapia (Oreochromis mossambicus). J. Food Proc. Engg. 34: 83-107.

26. Ng, W.K. and Bahurmiz, O.M. (2009): The impact of dietary oil source and frozen storage on the physical, chemical and sensorial quality of fillets from market-size red hybrid tilapia, Oreochromis sp. Food Chem. 113: 1041-1048.

27. Nishiya, K., Takeda, F.K., Tamoto, O., Tanaka, T., Fukumi T., Yashi K. and Aizawa, S. (1961): Studies on freezing of surimi (fish paste) and its applications (IV): on freezing surimi of Atka mackerel meat. Mon. Rep. Hokkaido Mun. Fish. Exp. Stn. 18: 391-397.

28. Noguchi, S. and Matsumoto, J.J. (1970): Studies on the control of the denaturation of fish muscle properties during frozen storage-I. Preventive effect of Na-glutamate. Bull. Jap. Soc. Sci. Fish. 36: 1078-1087.

29. Nopianti, R., Huda, N., Fazilah, A., Ismail, N. and Easa, A.M. (2012): Effect of different types of low sweetness sugar on physicochemical properties of threadfin bream surimi (Nemipterus spp.) during frozen storage. Int. Food Res. J. 19(3): 1011-1021.

30. Pan, J., Shen, H. and Luo, Y. (2010): Cryoprotective effects of trehalose on grass carp (Ctenopharyngodon idellus) surimi during frozen storage. J. Food Proc. Preserv. 34: 715-727.

31. Park J.W., Korhonen, R.W. and Lanier, T.C. (1990): Effect of rigor mortis on gel forming properties of surimi and unwashed mince prepared from Tilapia. J. Food Sci. 55: 335-360.

32. Park, J.W. and Lin, T.M.J. (2005): Surimi: Manufacturing and Evaluation. In: Surimi and Surimi seafood. $2^{\text {nd }}$ Edn. Park, J.W. (Eds.) Taylor and Francis, Boca Raton. pp. 33-40.

33. Park, J.W. and Lin, T.M.J. (2013): Surimi: Manufacturing and Evaluation. In: Surimi and Surimi seafood. $3^{\text {rd }}$ Edn. Park, J.W. (Ed.) Taylor and Francis, Boca Raton. pp. 21. 
34. Shenouda, S.Y.K. (1980): Protein denaturation in frozen fish. Adv. Food Res. 26: 275-311.

35. Siddaiah, D., Reddy, G.V.S., Raju, C.V. and Chandrasekar, T.C. (2001): Changes in lipids, proteins and Kamaboko forming ability of silver carp (Hypopthalmichthys molitrix) mince during frozen storage. Food Res. Int. 34: 47-53.

36. Suvanich, V., Jahncke, M.L. and Marshall, D.L. (2000): Changes in selected chemical quality characteristics of channel catfish frame mince during chill and frozen storage. J. Food Sci. 65: 24-29.

37. Suzuki, T. (1981): Fish and Krill protein: Processing Technology, Applied Science Publishers: Barking, Essex.

38. Taussky, H.H. and Shorr, E. (1952): A micro colorimetric method for the determination of inorganic phosphorus. J. Biol. Chem. 202: 675-685.

39. Velankar, N.L. and Govindan, T.K. (1958): A preliminary study of the distribution of non-protein nitrogen in some marine fishes and invertebrates. Proc. Ind. Acad. Sci. 47: 202-209.

40. Venugopal, V. and Shahidi, F. (1998): Traditional methods to process underutilized fish species for human consumption. Food Rev. Int. 14: 35.

41. Yang, J.T. (1961): The viscosity of macromolecules in relation to molecular conformation. Adv. Prot. Chem. 16: 323-400.

42. Yongsawatdigul, J., Park, J.W., Virulhakul, P. and Viratchakul, S. (2000): Proteolytic degradation of tropical tilapia surimi. J. Food Sci. 65(1): 129-133.

43. Yoon, K.S., and Lee, C.M. (1990): Cryoprotectant effects in surimi and surimi/mince-based extruded products. J. Food Sci. 55(5): 1210-1216.

44. Zhou, A., Benjakul, S., Pan, K., Gong, J. and Liu, A. (2006): Cryoprotective effects of trehalose and sodium lactate on tilapia (Sarotherodon nilotica) surimi during frozen storage. Food Chem. 96: 96-103. 